\title{
Teaching Cultural Studies; Teaching Stuart Hall
}

\author{
CATHERINE DRISCOLL \\ UNIVERSITY OF SYDNEY
}

I belong to a generation of cultural studies researchers for whom Stuart Hall was not the primary voice defining the field as I first encountered it. He was not even among the first wave of writers that I read or heard discussed as doing 'cultural studies'. Instead, I came to Hall's work from a distance defined by the history of cultural studies as a discipline; first by the diffusion of some of its most important interventions through other fields, so that it was not only people who said they were doing cultural studies who were taken up as key to the field, and second by the institutionalisation of a cultural studies canon in which Hall became only one voice, however influential. Nevertheless, by the time Hall died I had come not only to an enthusiastic appreciation of his work but to strongly feel my own indebtedness to it. I want to reflect here on how teaching cultural studies brought me to a close engagement with Hall's work, and how teaching keeps Hall's work and ideas alive when the exigencies of academic publishing might relegate him to citational history.

ISSN 1837-8692

Cultural Studies Review 2016. ( 2016 Catherine Driscoll. This is an Open Access article distributed under the terms of the Creative Commons Attribution 4.0 Unported (CC BY 4.0) License

(https://creativecommons.org/licenses/by/4.0/), allowing third parties to copy and redistribute the material in any medium or format and to remix, transform, and build upon the material for any purpose, even commercially, provided the original work is properly cited and states its license. 
I discovered cultural studies quite by accident at the beginning of my doctoral research. My undergraduate education had touched on both 'culture' and 'theory', but in much more traditional sociological and literary terms. If I ever heard Hall's name it was only in passing and had no traction. When I entered a 'Department of English with Cultural Studies' in 1992, initially planning a literary thesis, Hall was only one among many new names and voices I encountered as constituting this field. The long list of contributors on the front cover of Lawrence Grossberg, Cary Nelson and Patricia Triechler's Cultural Studies, published that year, is one representation of this multitude, complete with its promotional imperative: 'If you plan to continue living in America, read this book.' Although I wasn't in America the imperative felt real for a student already feeling at sea-with equal degrees of pleasure and anxiety-in a new intellectual world. Grossberg's collection circulated widely among students and relevant faculty, but it was not alone. Just as important in this time and place was Simon During's 1993 Cultural Studies Reader. That book doesn't list contemporary writers on the cover but is instead an anthology of theoretical pieces published over almost fifty years. Hall is here as well-indeed he's the only writer included twice-but I didn't much notice this given that Hall was not one of the writers being hotly debated around me. I also belong to that generation of cultural studies researchers for whom orientation in the field meant a theoretical orientation. We extensively debated many present and past theoretical and philosophical claims and interventions-back to Hegel and up-to-date. And while Hall was occasionally mentioned, his specific work had little traction in these discussions.

It would thus be easy enough to say that my early interest in cultural studies is exactly the kind of thing Hall regretted as the fate of cultural studies in the academy. Yet I certainly didn't understand myself as writing without a politics. For example, in taking ideas from the work of Gilles Deleuze (among others, but he was my favourite back then) to understand girls' magazines, 'Alice' stories or bridal culture, I felt I was insisting on an extension of both the content and the constituency that should interest feminist cultural analysis. Nevertheless, although more people cited Adorno than Hall when questioning my work then, by the time I came to read Hall's essays I was not only familiar with his figurehead role in cultural studies as a discipline but also of his subsequent critique of an overly theoretical version of the field. As a 
cultural studies convert of the early 1990s with a passion for post-structuralist theory, when I first picked up one of Hall's work with real intent to read it I expected to find him not on my side.

My image of Hall as a founding but now disaffected father figure was both incomplete and simplistic. It became possible because I had never done undergraduate cultural studies and had thus never been required to read him although I was now surrounded by people who found him too familiar to heatedly debate. Thus I didn't always recognise the extent of Hall's influence on, or the importance of Hall's interpretations of, the things I was reading. Then in 1995 I was asked to tutor an undergraduate course on popular culture that included a plethora of references to Hall: to his early account of 'Encoding and Decoding' in popular media, to his contributions to 'Birmingham School' projects, including the justly famous collections Resistance Through Rituals: Youth Subcultures in Post-War Britain and Policing the Crisis: Mugging, the State and Law and Order, and to his theoretical accounts of popular culture, representation and identity. ${ }^{1}$ It was finally teaching that required I focus on what Hall had written rather than what he had institutionally achieved or his place in debates about what cultural studies had become.

The following quotation from 'Notes on Deconstructing the Popular' is representative of what I discovered at this time in Hall the theorist:

First, I want to say something about periodizations in the study of popular culture. Difficult problems are posed here by periodization-I don't offer it to you simply as a sort of gesture to the historians. Are the major breaks largely descriptive? Do they arise largely from within popular culture itself, or from factors which are outside of it but impinge on it? With what other movements and periodizations is 'popular culture' most revealingly linked? Then I want to tell you some of the difficulties I have with the term 'popular'. I have almost as many problems with 'popular' as I have with 'culture'. When you put the two terms together the difficulties can be pretty horrendous. ${ }^{2}$

Although first published in 1981 this passage still offers insightful questions for undergraduate students being asked to problematise commonsense understandings of popular culture as a reflection of unspecialised average taste. It also offers provocative questions for researchers grappling with how to discuss the articulation 
between popular forms and social change. Hall's capacity to package complex debate in an accessible format, evident in this passage, isn't equally at the forefront in all his texts. But I think Hall's essays particularly merit the pedagogical contextualisation and explication they sometimes require because of his emphasis on historical change.

I've now taught many versions of an introduction to cultural studies, to youth studies or to critical cultural theory, in which Hall offers valuable entry points and works as the kind of productive interlocutor to whom students can be brought back across the course to trace their own developing understanding. Even when his work is transparently outdated, say by changes in media production or changed relations between models for successful adolescence and commercial youth culture, it can help students see relations between the work cultural studies might do (even sometimes feels compelled to do) and the world from which it emerges. Hall also often offers a history of ideas tailored to developing both critical skills and reflexive research practice. His essay 'The Work of Representation' is exemplary, guiding students through the fog of intellectual fashion to see the connections and differences between how representation might be understood utilising the work of Ferdinand de Saussure, Roland Barthes and Michel Foucault (with Marx, Gramsci and Althusser standing in the background but close enough to be seen by more adventurous students). ${ }^{3}$ This essay alone is a service to teaching cultural studies few have equalled. It even comes with a set of associated (now online) videos featuring Hall's explanations, tailor-made for classroom use because Hall was obviously thinking as a teacher when he developed that material, as so few leading thinkers do. 4

One of the interesting challenges of teaching Hall today is that he can be utilised by cultural studies at its most disingenuously populist-'Hey, kids, lets expose the workings of power in everyday life!'-but also to elaborate its most continually urgent critical foundations. Hall is always engaged with the categories through which as subjects of the modern world we strive-and are required to strive-to know and represent ourselves, even as 'Cultural Studies' became one the categories through which such representation can proceed.

It seems appropriate to end with one of Hall's comments on the failings-or, better, problem - of cultural studies as he saw it in later years. In 2012, in response 
to Sut Jhally's question, 'What happened to the political and economic dimensions of the formative period of cultural studies?' (a question which begs for a story about decline) Hall first dismisses a phase of cultural studies that he believes 'tried to forget that it had a political edge, or political dimension' in a 'splurge of high theory', then acknowledges that he is not 'against theory ... I don't believe that we can live without, understand things without, theoretical concepts'. He both doubts that cultural studies is 'in a good place' to understand the economic dimensions necessary for 'conjunctural analysis of the present', then acknowledges that in fact it is cultural studies scholars who 'do understand that the cultural is constitutive of political crisis', positioning them to make a 'deeper analysis' than those from more 'traditional' disciplines, on the condition that they do not neglect economic and political questions. This ambivalence is useful, resonating with doubts every researcher should feel and unable to be reduced to anything other than a question about how cultural studies might proceed that is answerable only with specific reference to the context of their research. Finally, Hall reminds himself of the practical diversity of cultural studies, and that stories about the field having 'lost its way' are itself reductive, and he laughs at his own headmasterly tone before declaring that he never wanted to set himself up as adjudicating the correct form of cultural studies. ${ }^{5}$ Hall's frequent discussion of the state of the field aligns him with many other senior cultural studies scholars, usually but not always men, who have written about the decline of the field since a heyday that was theirs. But even in this mode Hall remains attuned to the importance of seeing cultural studies as a history of ideas which remains unfinished, and thus remains useful for any classroom in which those present are looking for the significance of the work they do rather than taking it for granted.

It's understandable that Hall in this retrospective reflective mode came to dominate how he was positioned in the field. Clearly it was a subject on which he was often invited to speak, and one for which he had a unique authority. But this is also unfortunate because it somewhat obscures his contributions to cultural studies as an intellectual and a teacher. Chief among these for me is Hall's insistence on the historically specific conjuncture that produces, and thus necessarily changes, all of our most important ideas, including 'the popular', 'culture', 'representation', 'politics', 'identity' and even 'theory'. In this Hall is indebted not only to Gramsci, as 
he suggests in that interview with Jhally, but also to Raymond Williams, whose work I came to appreciate far more quickly than Hall's. ${ }^{6}$ But it is Hall's teacherly attention to critical tools that demand we pause and ask how we understand our world that gives him a longer and more flexible life for cultural studies curricula around the world. Today, of course, Hall's insistence on the importance of historicising such tools can also be usefully turned to contextualising his own work. I have found that setting multiple pieces of Hall's, written at points when he had different interests and approaches, is particularly helpful to clarifying the importance of an historical perspective on the ideas we choose.

In the heady rush of finding and enjoying new things to say about new things it is easy to forget that survey-style teaching and research-rather than canonisation itself, although the two are inextricably linked-is an important service to a field. At its best, the kind of field/introduction/survey course on which Hall is required reading is not only a reflexive form of training in the field that helps students understand and contextualise what else they are reading. It is also a type of memory work-reminding us how debates and ideas that still shape us emerged and have changed, requiring us to reflect on their contextual specificity and the context in which we use them now, or choose not to. A field without such a good memory easily gets stuck in celebrating novelty; fashionable terms and names always fighting off a kind of planned redundancy. This is especially true for a field like cultural studies with its orientation towards 'the present conjuncture', as Hall would put it. Reading Hall in order to teach him, and teaching Hall today, is a process of rediscovering what has not changed in the face of so much change. Whether our own focus, for teaching or research, is on media, on popular culture more generally, on the relation between academic and activist work, on race, on identity, or even on youth and gender (on both of which he had less directly to say), paying attention to what Hall does and doesn't discuss, with what conceptual tools, and under what circumstances these are challenged and change, thrusts us out of self-involved cycles of intellectual fashion and back to a ground which is not only about the politics of everyday life but also about the politics of an intellectual life that needs to be just as historically aware. 
Catherine Driscoll is Professor of Gender and Cultural Studies at the University of Sydney.

-Notes

${ }^{1}$ Stuart Hall, 'Encoding/decoding', in Centre for Contemporary Cultural Studies (ed.), Culture, Media, Language: Working Papers in Cultural Studies, 1972-79, Hutchinson, London, 1980, pp. 128-38; John

Clarke, Stuart Hall, Tony Jefferson and Brian Roberts, Resistance Through Rituals, Centre for Contemporary Cultural Studies, Birmingham, 1975; Stuart Hall, Chas Critcher, Tony Jefferson, John Clarke and Brian Roberts, Policing the Crisis: Mugging, the State, and Law and Order, Macmillan, London, 1970.

2 Stuart Hall, 'Notes on Deconstructing the Popular', in Raphael Samuel (ed.), People's History and Socialist Theory, Routledge \& Kegan Paul, London, 1981, p. 227.

3 Stuart Hall, 'The Work of Representation' in Stuart Hall (ed.), Representation: Cultural Representations and Signifying Practices, Sage, London, 1997, pp. 13-74.

${ }^{4}$ Stuart Hall and Sut Jhally, 'Representation and the Media: Featuring Stuart Hall', The Media Education Foundation, <https://www.youtube.com/watch?v=aTzMsPqssOY>.

${ }^{5}$ Stuart Hall, 'Stuart Hall: Politics' Place in Cultural Studies', Sut Jhally (ed.)

<https://www.youtube.com/watch?v=EyuKRwd5Lqg>.

${ }^{6}$ See Hall's discussion of Williams in Stuart Hall, 'Cultural Studies and its Theoretical Legacies', in Lawrence Grossberg, Cary Nelson and Paula Treichler (eds), Cultural Studies, Routledge, New York, 1992, pp. 277-86.

\section{-Biblography}

Clarke, J., S. Hall, T. Jefferson and B. Roberts, Resistance Through Rituals, Centre for Contemporary Cultural Studies, Birmingham, 1975.

Hall, S., 'The Work of Representation' in Stuart Hall (ed.), Representation. Cultural Representations and Signifying Practices, Sage, London, 1997.

Hall, S., 'Cultural Studies and its Theoretical Legacies', in L. Grossberg, C. Nelson and P. Treichler (eds), Cultural Studies, Routledge, New York, 1992.

Hall, S., 'Notes on Deconstructing the Popular', in R. Samuel (ed.), People's History and Socialist Theory, Routledge \& Kegan Paul, London, 1981.

Hall, S., 'Encoding/decoding', in Centre for Contemporary Cultural Studies (ed.), Culture, Media, Language: Working Papers in Cultural Studies, 1972-79, Hutchinson, London, 1980. 
Hall, S. and S. Jhally, 'Representation \& the Media: Featuring Stuart Hall', The Media Education Foundation, <https://www.youtube.com/watch?v=aTzMsPqssOY>.

Hall, S., C. Critcher, T. Jefferson, J. Clarke and B. Roberts, Policing the Crisis: Mugging, the State, and Law and Order, Macmillan, London, 1970. 